\title{
Analysis on Transfer of Audio-Visual Education Resources under Urbanization Background
}

\author{
Fuqiang Tian \\ College of Economics and Management, Xi'an University, Xi' an, China, 710065 \\ tianfuqiang2004@126.com
}

Keywords: Urban and rural coordination; Audio-visual education resources; Development strategy; Innovation; Transfer

\begin{abstract}
It intensifies the lack of audio-visual education resources that the children of migrant workers receive education in the city. The strategy of transfer of audio-visual education resources is important for promoting the overall planning of urban-rural audio-visual education. With urbanization, the urbanization of teachers and facilities for audio-visual education also begin, it is necessary to make allocation plan for rural schools under the urbanization background. Rural audio-visual education should pool resources, promote quality and make reserved school to be school with high level and good allocation. The urbanization of added education technology resources can help to coordinate the development of urban and rural, ensure a reasonable and order transfer of rural teachers of audio-visual education to the city and enhance the audio-visual educational level of the rural reserved schools. The problem of investment of audio-visual education should be solved by establishing educational land ticket market, reinvigorating the idle land resources of closed schools and establishing audio-visual education fund with land income.
\end{abstract}

\section{Introduction}

Under the guidance of Nan Guonong's thought "Harmony is most precious, harmony but difference, seeking sameness but keeping difference" ${ }^{\text {"[1] }}$, it is very necessary of discussing the urbanization of teachers and facilities of technical education and the coordination of rural and urban audio-visual education under the background of population urbanization.

\section{Background of Coordination of Urban and Rural Audio-Visual Education}

There are many researches for the coordination of urban and rural audio-visual education such as research on information resources ${ }^{[2][3]}$ and its use ${ }^{[4][5][6][7]}$ for distance education in rural school, research on the new channel of coordinated development of urban and rural information education level and integration of course resources, research on technological literacy ${ }^{[11]}$ and ability ${ }^{[12]}$ for distance education of rural teachers, research on information education ${ }^{[13]}$ of rural students and research on the management ${ }^{[14]}$, construction ${ }^{[15]}$, supply system ${ }^{[16]}$, evaluation ${ }^{[17]}$, mode ${ }^{[18]}$, training $^{[19]}$, practice $^{[20]}$ and resources ${ }^{[21]}$ of RDE project which indicate the effectiveness of RDE project. There are large differences on many aspects such as teacher's quality, the allocation and use of educational technology facilities and educational information level between different regions and between the city and countryside in the same region. Under the background of coordination of urban and rural, it is very significant to reduce the difference of information education level between city and rural area, completely carry out rural information education, promote technical education quality and ability of rural primary and middle school teachers and effectively improve the effectiveness of education. Coordination of urban and rural audio-visual education must cope with the serious challenges to the cause of education brought by the adjustment of economy structure in the next 30 years. Under the background of significant adjustment of urban and rural layout, the future research and layout of urban and rural balance for audio-visual education should be considered seen from the three profound shifting of perspectives. RDE project has made great achievements in underdeveloped areas, but the number of teachers for audio-visual education is limited, the level of teachers need to be improved, and the existing audio-visual education facilities 
need to be reinforced. There are large differences between the level of audio-visual education in urban and rural areas. It is the main reason that the relevant financial allocation is not enough to provide education technology facilities to keep up with the development trend of information technology. It intensifies the lack of audio-visual education resources that the children of migrant workers receive education in the city. Many students face the problem that they are still out of school after entering the city, even if they are in the class overstaffed, the effectiveness and stability of educational quality are affected by the lack of audio-visual education facilities resources.

\section{Urbanization Trend of Educational Resources}

Urbanization of educational resources is a new topic. Under the present background of no coordination of information technology, strategic planning for coordinating urban and rural educational technology is very important for information technology education under the background of population urbanization.

Three Trends of Urbanization. In the next 30 years, the transformation of economical structure and good momentum for sustained growth of economy are determined by the transformation of growth mode that domestic demand-led replace the exports and investment-led. The consumption subject which drive the domestic demand can be divided into three parts, the first part is 500 million urban population, the second part is 260 million floating population (most of them are migrant workers) and their family members, the total number of migrant workers and their family members is about 500-600 million; the last part is nearly 300 million population left behind in rural areas and mainly rely on agricultural production. The second part is the group with the greatest consumption potential, they are the migrant workers and their family members who work in the city long time and their children and family members live in the countryside long time. This part of floating population are the growth engine of urban economic and their employment are very important for urban construction as one of the main workforce for urban construction. But the consumption of this part of population are mainly carried out in rural areas that their family members live in the countryside and their children receive education in rural areas. Their consumption is restricted in rural areas which can not effectively drive domestic demand.

Urbanization of Migrant Workers. The future economic growth mainly depend on the growth of domestic demand promoted by urbanization, so urbanization of migrant worker is an inevitable trend. If the problem of education of migrant workers' children is solved, their family members actually go to the city and set down in the city with them that will drive the consumption of education, renting house and living in order to increase the domestic demands. It will promote the stable improvement of the educational level of migrant workers' children as a big group that migrant workers' children receive urban education, and it is very important for economic transformation strategy. With the appropriate transformation of educational system, the allocation of educational resources should comply with the development trend of urbanization.

Urbanization of Migrant Workers. It was published that the proportion of urban population is closed to $50 \%$ of total population on April 28, 2011. It is assumed that school-aged children with the same ratio study in urban school. The authoritative figure in 2006 told us that the proportion of teachers in rural middle and primary school below the country level is 80 percent of all the teachers in middle and primary school in the country, and the proportion of teachers in urban middle and primary schools is very small. The urbanization of teachers resources is an inevitable trend under urbanization background. A large number of parents go to the city, and the same proportion of children have went or will go to school in the city, the original proportion of teachers stay in the rural areas because of the system design without transfer of teachers' position and face with secret worry of no arrangement. Starting the system design for urbanization of teachers resources in a good time can avoid the waste of human resources that urban school lack teachers and rural teachers are idle. The urbanization of schoolhouse resources, investment in the fixed assets and educational facilities are carried out with urbanization of teachers resources.

Importance of Rural Audio-Visual Education under Urbanization Trend. Educational resources face with the big trend of urbanization allocation, it must be realized that the current 
development level of rural audio-visual education can not satisfy the needs of educational level of urban and rural balance. The popularization and improvement work of level of rural audio-visual education should be done well in the aspects of total amount and resources allocation.

\section{Urbanization of Educational Technology Resources}

Paying More Attention to Promote Quality of Future Rural Audio-Visual Education. A long term plan should be made for suiting the needs of future urbanization and enhancing rural audio-visual education. There are still more than 300 million population live in rural areas calculated according to 1,400 million as the peak population even if the urbanization ratio is increased by 74 percent after 30 years. But there are a large number of children receive education in rural areas even if the urbanization ratio is increased. It is urgent to solve the problem of information education for these students, improve the audio-visual education level of teachers and provide quality education resources for the left-behind children.

Pooling Rural Audio-Visual Education Resources. The work of canceling teaching centers and merging primary and middle schools is moving rapidly. Building school by raising fund increased the burden of farmers and the pressure of social stability in the 1980s and 1990s. It was caused that a large number of resources are idle and wasted although building school by raising fund solve the school conditions for students in a certain period of time. At present, the schoolhouses are idle, and the problem of erosion of assets and land is very serious. It lack strategic plan for education and be a warning to the improvement of rural audio-visual education level that each village build a school which increase burden of farmers.

Strategic Layout and Popularization for Audio-Visual Education. If canceling teaching centers and merging primary and middles schools are considered when the schools are built, doing well strategic work of centralized building of schools can contribute to a harmonious society by reducing construction fund, reducing burden of farmers and reducing stability pressure of society. For rural audio-visual education under the background of urbanization, it must be considered that there may be a larger number of schoolhouse are idle and a large number of schools will be closed if a large number of information education facilities and investment for educational technology facilities are widely provided for rural middle and primary schools.

Reformulating Strategy Help to Promote Audio-Visual Education Quality. Information economy change rapidly, educational department should distribute teachers and facilities for audio-visual education to the schools not be canceled and merged in the decades ahead and adopt the allocation with same level, high starting and high quality in urban and rural during the first stage of investment in order to reduce the technical difficulty of popularization of audio-visual education for administrative department for education, alleviate the financial pressure, make prospective strategic layout, get rid of difference of urban and rural educational technology level and improve the level of teachers and facilities for rural audio-visual education.

\section{Allocation Strategy for Educational Technology Resources}

There still be many differences between the educational technology level in urban and rural. It is very necessary to carry out the coordination of the educational technology level in urban and rural. The canceling teaching centers and merging primary and middles schools are caused by the wide building of school without consideration of planning. Audio-visual education facilities should be allocated in the schools left but not in each school to make the schools left to be the schools with high level and perfect allocation as the urban schools. At the same time, the additional educational technology resources and teachers should be transferred following the parents and students under urbanization. 


\begin{tabular}{|l|l|l|}
\hline G & E & F \\
\hline C & D & \\
\hline A & B & \\
\hline
\end{tabular}

Figure1. diagrammatic sketch for allocation of educational resources

As shown in Fig. 1, A expresses the current covered population for rural audio-visual education, B expresses the level of audio-visual education, the width expresses the number of students, the height expresses the level of audio-visual education; F expresses the current covered population for urban audio-visual education and the level of audio-visual education, the width expresses the number of students, the height expresses the level of audio-visual education. In the foreseeable future, the urbanization ratio of rural labor force will be increased following the advance of three strategies above, and the rural student will rapidly reduced, it is assumed that the number of rural students will be reduced by $50 \%$ and be A; party B is the students transferred from rural school to urban school, the audio-visual education resources of these students will be transferred to the schools left and be used to improve the level of audio-visual education for partial students, it is assumed that the increased part is $\mathrm{C}$. The existing level of audio-visual education increased is not high as the original urban partial level of audio-visual education, but the combined effect of resources must largely improve the level of rural audio-visual education and help to coordinate audio-visual education in urban and rural. The investment and teachers should be increased for part $\mathrm{G}$ in order to improve the level of audio-visual education. The investment for the audio-visual education of the students transferred from rural school should be increased for B, D and E. The investment gap of teachers and facilities is brought by the system design under strategic transfer. The audio-visual education fund established by income of land after canceling teaching centers and merging primary and middle schools will be the supplement for investment of audio-visual education facilities of party B, D and E. The land resources only be used to build new urban schoolhouse in order to solve the schooling problem of migrant workers' children under the background of lacking of land resources after entering the educational ticket market. Most of these teachers are recruited from teachers in urban and rural areas.

Teachers Mobility System of Rural Audio-Visual Education. Lacking teachers for audio-visual education is a common problem in most of rural areas. Based on the consideration of that a large number of rural teachers are idle after canceling teaching centers and merging primary and middle schools, for solving the problem of lacking teachers and fully making use of these superfluous teachers resources, young and middle-aged teachers are trained for audio-visual education. The rural teachers will be trained one time every five years. Every teacher has an opportunity for a year's mid-career studies to learn educational technology, master the newest educational knowledge and improve the level of audio-visual education. The free flow of urban and rural teachers should be carried out, and the rural teachers should be encouraged to flow to the new schools for the children of peasant workers and the schools with enrollment for the children of peasant workers. Full faculty employment system should be implemented for new teachers in order to carry out the free flow of teachers under the background of coordination of urban and rural audio-visual education. Teachers should be trained and qualified to meet the demands of future audio-visual education in the principle of no added positions and no lay-offs. The teachers of new urban schools mainly or fully be recruited from the rural teachers with qualified educational technology level. Full faculty employment system should be implemented for the new teachers of the schools for the children of peasant workers.

Coordination of Urban and Rural Audio-Visual Education Resources. It should be done to know the school will be left or closed, increase the investment for the facilities of rural audio-visual education and enhance the level of audio-visual education of the school left in the process of urbanization. By 2020, the level of audio-visual education of the rural schools should reach the average level of the urban schools, and the coordination of urban and rural audio-visual education should be carried out. The fixed assets investment of future audio-visual education should be 
implemented according to the urbanization ratio of rural students increased stably. The fixed assets investment of audio-visual education should be added according to the ratio of urban and rural students. After the equalization of the level of audio-visual education in urban and rural is achieved, the fixed assets investment of audio-visual education should be suit with the increasing urbanization ratio and transfer added proportion of investment of audio-visual education to the city gradually. At present, it is hard to carry out the coordination of urban and rural audio-visual education resources in many areas. But the relevant department should make preparation, make strategy and guide the effective allocation of audio-visual education resources.

\section{Measures for Allocation of Educational Technology Resources}

The promotion of the teachers, facilities and level of future audio-visual education should be considered from the strategic level, and the financial investment should be enhanced to fundamentally change the situation that the investment of rural audio-visual education is dispersed and the level of rural audio-visual education is low.

Establishing the Future Allocation Plan for School under Urbanization Background. At present, the proportion of urban population is almost 50 percent of total population. The proportion of urban population will be almost 74 percent of total population calculated according to the urbanization ratio $0.8 \%$ every year after 30 years. It is assumed that the ratio of receiving education of children is closed to the ratio of total population distribution, at present, the ratio of the students of rural middle and primary schools should be 50 percent of total number of students, there should be a $16 \%$ decrease in the number of rural students after 10 years, there should be a $32 \%$ decrease in the number of rural students after 20 years, and there should be a $48 \%$ decrease in the number of rural students after 30 years. In the next 10 years, there will be a $16 \%$ decrease in the number of rural schools, the teachers with the same ratio will be left, and the reallocation of audio-visual education resources should be implemented. After 30 years, the rural students, number of schools, number of teachers and audio-visual education resources will be decreased by 52 percent of the current total amount. The situation is not included in above calculation that there is no reasonable allocation for school resources and teachers resources. As aforesaid, the proportion of teachers in rural middle and primary schools below country level is 80 percent of all the teachers in the country in 2006, this situation tell us that the allocation of teachers of middle and primary schools in urban and rural areas is not reasonable. These idle teachers are urgent to be trained who should be orderly transferred to the new schools for the children of peasant workers in the city and the schools lack teachers because of the enrollment for the children of peasant workers according to reasonable system and platform. Unlocking the shackles of teachers brought by system can make the rural teachers to enter to the schools lack teachers, ensure the reasonable allocation of teachers, ease the situation of lacking audio-visual education resources for urban schools because of the entering of the children of migrant workers and ensure the popularization and improvement of educational technology.

The link of educational system in urban and rural areas should be discussed from the flow of students to ensure the free flow of educational resources in the areas and solve the problem that the students need receive urban audio-visual education after enter the city. For the idle teachers, more opportunities to be teachers in the urban schools should be provided for the idle rural teachers to arouse the initiative of teachers in the case of retaining their organizational positions. Audio-visual education resources should be centrally distributed to the reserved schools in future to ensure the effective use of audio-visual education resources in the case of that the total audio-visual education resources in rural schools are not enough. The level of audio-visual education of reserved schools will be largely increased by centrally investing much fund for audio-visual education in order to make the level keep up with the rapid development of audio-visual education. The future outflow trend of labor in areas should be investigated and forecasted according to the flow trend of population, based the forecast to the outflow trend of labor, the number transition diagram of students in future and different term should be created, and the requirements diagrams for schools in the relevant term should be created according to the standards of state in order to determine the 
reasonable number, scale and place of school. Moderate advance planning can be implemented to ensure that the students can receive education and the reasonable distribution of educational resources. The requirements of audio-visual education for the students left behind must be met according to a reasonable planning. In the 1980s and 1990s, building primary school in each village and building middle school in each town wasted a large number of educational resources, increased the burden of farmers and affected the stability of society. The allocation plan of schools in urban and rural areas should be considered according to the flow trend of labor and the development potentials of urbanization in order to determine the schools reserved forever, schools reserved for long term, schools reserved for longer term, schools reserved for medium term, schools reserved for short term and temporary schools reserved and make the level of audio-visual education of every school reach the average level of urban and rural audio-visual education, and at the same time, the investment strategy of teachers and facilities of schools with different level should be considered in the field of canceling teaching centers and merging primary and middle schools in urban and rural areas.

The level of audio-visual education of rural reserved schools should be enhanced, and the investment of the reserved schools for audio-visual education should be gradually increased according to designed term to carry out coordination of audio-visual education in urban and rural areas. The teachers and facilities of closed schools should be transferred to the reserved schools, and more financial support and resources should be provided for the reserved schools in order to improve the level of audio-visual education. Harvesting strategy should be adopted for audio-visual education of the closed schools to meet the demands of information technology education of students during a certain period of time and provide service for the normal teaching of school before merging.

Table 1 investment strategy of audio-visual education for different schools in different allocation

\begin{tabular}{cccc}
\hline $\begin{array}{c}\text { conditions and measures } \\
\text { of schools }\end{array}$ & $\begin{array}{c}\text { audio-visual } \\
\text { education with high } \\
\text { level }\end{array}$ & $\begin{array}{c}\text { audio-visual } \\
\text { education with } \\
\text { medium level }\end{array}$ & $\begin{array}{c}\text { audio-visual education } \\
\text { with low level }\end{array}$ \\
\hline reserved schools forever & more investment & $\begin{array}{c}\text { special } \\
\text { development } \\
\text { specialization }\end{array}$ & specialization, merging \\
$\begin{array}{c}\text { reserved schools for } \\
\text { longer term } \\
\text { reserved schools for a } \\
\text { short term }\end{array}$ & $\begin{array}{c}\text { specialization, } \\
\text { increase investment } \\
\text { maintain }\end{array}$ & reduce investment & maintain or abandon \\
\hline
\end{tabular}

Educational Ticket System Solve the Problem of Investment of Audio-Visual Education. Land ticket is a kind of trading platform for land system. For ensuring the food safety, the government set the red line of farmland area of 18 million mu and require the local department to abide by this red line, and construction land can not break the red line to ensure that the red line is not broken. For relieving the situation that the development of the city often break the construction land index, it is stipulated by the state that $1 \mathrm{mu}$ cultivated land is used for construction, $1 \mathrm{mu}$ non-cultivated land must be reclaimed. Besides of the construction index given by the state, it is allowed by the state that local department can change the waste land to cultivated land, and change the cultivated land with the same areas to construction land index. So the total amount of cultivated land in this area is not reduced, and the construction speed of urbanization is not affected. Land ticket is the index arrangement to solve this problem. Because the reclamation area is not closed to the area need additional construction index, it often occur that another city can not use this $1 \mathrm{mu}$ of construction index because of the bigger gap of construction land index when $1 \mathrm{mu}$ waste land is reclaimed in this area. The gap of construction index is more bigger and bigger, there are more and more additional land index in some areas. For resolving this contradiction, the construction of land trading platform have been tried in Chongqing, Chengdu and other areas, the land index in urban and rural areas of different areas were purchased in the land trading center provided by land trading 
platform, and the object of trading is just index but not real land. For example, villager of A village obtain $10 \mathrm{mu}$ of farmland by reclaiming the waste land, he can sell the land index of $10 \mathrm{mu}$ in land trading center after that his land reclaimed pass the examination of relevant department and be transferred to farmland. Many units (for example, developers ) will make implement auction of the $10 \mathrm{mu}$ farmland index in trading market who are urgent to obtain the urban construction land index, the unit with the highest price will be the gainer of farmland index. After trading, the owner of property right of the $10 \mathrm{mu}$ farmland is unchanged, and villager of A village continue to cultivate the farmland. At present, the trading price of $1 \mathrm{mu}$ land is about 10, 000 yuan, villager of A village can obtain 1,000,000 yuan as one-time gains by reclaiming $10 \mathrm{mu}$ farmland. For the buyer of the land, developer B spend 1,000,000 yuan on the land ticket of $10 \mathrm{mu}$, the money is not the cost of purchasing land but the acquisition cost of additional construction land index. Comparing with the developer who can easily obtain construction land index, the money spent by developer B is an additional cost. After getting land ticket, developer B must participate in the auction of construction land in the city in order to get the construction land. Developer can use the land ticket if he get urban construction land by auction. Developer also can transfer the land ticket to the developer lack land ticket if it is hard for him to get desirable urban construction land. It is just the first part of the problem that developer can not get land ticket index. The next links also be indispensable such as participating in auction for urban construction land and paying purchasing cost of land after winning the auction. The urban construction land index is rare, so the farmland index purchased in land ticket trading market obtained by reclaiming the waste land can help the construction units need construction land index to resolve their urgent problem. It can promote the food safety and ease the strain of urban construction land to encourage villagers to change the idle land to farmland. At the same time, the villagers reclaim the idle land can obtain extra income. The units lack urban construction land can get construction land index by paying a certain cost. This systematic innovation can ensure that land is fine used which is the new exploration of land system reform.

Many closed schools have not industrial exploitation conditions which are distributed separately in rural areas. It is easy to loss the idle land resources. The land ticket system should be established in which the re-cultivation of the idle land should be implemented by using the gap of urban construction land. The income of re-cultivation or lease is owned by the original village, town or state. If the idle resources are purchased in educational ticket market, the income of land trading is owned by village, town and state. The income owned by village and town should be used to establish audio-visual education fund and improve the update of audio-visual education facilities and the teachers' training of the new schools in which the students of this village and this town study. The income owned by state should be used to establish audio-visual education fund and promote the level of audio-visual education by distributing uniformly.

At present, most of land ticket market are integrated ticket market. The educational land market is a system innovation. It is hard to enter the urban schools full of students for rural students. Education system should be designed again and a lot of schools should be built for the students entered the urban schools from rural schools. It is assumed that the proportion of urban and rural education resources to the total education resources in the country is closed to the proportion of urban population to the total population $(50 \%)$, after 10 years, there will be a $16 \%$ decrease in the number of rural students, and at the same time, there will be a $16 \%$ increase in the number of urban students in middle and primary schools; after 20 years, there will be a $32 \%$ decrease in the number of rural students, and at the same time, there will be a $32 \%$ increase in the number of rural students in middle and primary schools; after 30 years, there will be a $48 \%$ decrease in the number of rural students, and at the same time, there will be a $48 \%$ increase in the number of rural students in middle and primary schools. The new schoolhouse must be built for the situation. The establishment of educational land ticket market can solve the problem that there is no enough land for the construction of urban school. It must be stipulated that the provider of land ticket must be the land index obtained after the reclamation of the land of schoolhouse after merging of schools. The purchase of land ticket must be the gainer of land for building new schoolhouse. The schools can gain land index in this market which can not gain land index in general land ticket trading 
market because of the high price of land ticket. The main source of rural land tickets are the idle land in rural school, so the supply of land is rich. The income of land trading should be used for the allocation of audio-visual education facilities and the teachers' training of audio-visual education for new schools to promote the level of educational technology for teachers.

In the information age, the level of educational technology facilities should keep up with the requirements of educational technology development. The investment gap is very large in large rural areas, it should be ensured that the facilities of audio-visual education can comply with the development of educational technology. Coordination of audio-visual education in urban and rural should adapt the three major trends of urbanization in the next 30 years and fully make use of limited resources to improve rural audio-visual education.

The establishment of educational market can reinvigorate idle land resources. Idle school resources should be reasonably arranged which are easy to belost. Provincial educational ticket trading system should be established that firstly the original schoolhouse should be broke or sold and the idle land should tilled again, and then income can be obtained by purchasing the land ticket after reclamation based on the fixed property right. This income is up to 100,000 yuan, and the reclamation also increase the cultivated land and ensure the safety of food, and the land still be owned by the state, town and villages. The purpose of this action is avoiding the loss of the idle land of state, town and villages. The land income is used for establishment of audio-visual education fund and development of local audio-visual education work. Urban new schools are the only qualified purchaser of the land for trading. The limited land resources should be fully used to develop the audio-visual education work by introducing land ticket system in the case of that the property right of land is not changed and the loss of land of state, town and villages is avoid.

Table 2 income fund of educational tickets be used for development of audio-visual education reclamation for the idle land carrying out coordination of audio-visual education in urban and rural areas because of the urbanization of by gradually promoting the urbanization of students, teachers and resources. rural students

\begin{tabular}{|c|c|c|c|c|}
\hline $\begin{array}{l}\text { land still be } \\
\text { owned by } \\
\text { state, town } \\
\text { and village. }\end{array}$ & $\begin{array}{l}\text { the increasing } \\
\text { of land trading } \\
\text { indicators } \\
\text { caused by } \\
\text { reclamation of } \\
\text { land. }\end{array}$ & $\begin{array}{l}\text { income of tillage } \\
\text { or lease be used to } \\
\text { establish } \\
\text { audio-visual } \\
\text { education fund }\end{array}$ & $\begin{array}{l}\text { urban new schools for the } \\
\text { children of peasant } \\
\text { workers have the first } \\
\text { refusal of the land ticket } \\
\text { to obtain land use index }\end{array}$ & $\begin{array}{c}\text { teachers receive an } \\
\text { off-job training every five } \\
\text { years to learn } \\
\text { audio-visual education } \\
\text { and professional } \\
\text { knowledge }\end{array}$ \\
\hline $\begin{array}{l}\text { income of } \\
\text { tillage or } \\
\text { lease }\end{array}$ & $\begin{array}{l}\text { educational } \\
\text { ticket trading } \\
\text { obtain a big } \\
\text { profit }\end{array}$ & $\begin{array}{l}\text { developing the } \\
\text { local audio-visual } \\
\text { education }\end{array}$ & $\begin{array}{l}\text { improvement of the level } \\
\text { of audio-visual education } \\
\text { for the children of peasant } \\
\text { workers }\end{array}$ & $\begin{array}{l}\text { improvement of the level } \\
\text { of audio-visual education } \\
\text { for teachers }\end{array}$ \\
\hline
\end{tabular}

\section{Acknowledgements}

The author acknowledge the Social Sciences Planning Foundation of Xi'an in 2017 (Grant: 17J113), Xi 'an Science and Technology Plan in 2017- Soft Science Research Project (Research on wetlands ecological requisition-compensation balance for Quality Xi 'an), the Rural Reform and Social Economic Development Research Foundation of Anhui University (Grant: ADNY201503), the Social Sciences Planning Foundation of Xi' an 'Xi' an University Fund Project" (Grant: 16WL02), the Sciences and Technology Planning Foundation of Xi'an "Xi'an University Fund Project" (Grant: CXY1531WL04).

\section{References}

[1] Guonong Nan. Formulation and Development of Information Education Theory System[J]. 
E-education Research, 2009(8):5-9.

[2] Qingtang Liu, Mei Liu, Yanhui Xie, Hao Li, Min Hu. Research and Application of Educational Resources Classification System for Villages[J]. E-education Research, 2010(12):57-63.

[3] Xiaoyong Hu, Bin Zhan, Tiesheng Hu. Research on Construction Status and Development Strategy of Regional Education Information Resources[J]. China Audio-Visual Education, 2007(6):56-61.

[4] Yuanzhi Tong. Exploration of Effectively Using Modern Education Resources in Rural Middle and Primary Schools[J]. E-education Research, 2009(9):88-90.

[5] Zhiping Dang. the Current Situation and Improvement of Digital Education Resources Construction of Smaller Schools in Rural Areas[J]. Journal of Teaching and Management, 2017(1):19-21.

[6] Daoli Jiao, Xinxian Zhang. Investigation and Research on Construction and Application of Distance Learning Teaching Resources in Primary Schools of Poor Areas - with the Schools in Villages and Towns of Yuzhong Country, Gansu Province as Example[J]. E-education Research, 2009(1):82-85.

[7] Hongguang Peng, Junfen Lin. Mechanism and Strategy of Promoting the Balanced Development of Compulsory Education with Information[J].China Audio-Visual Education, 2010(10):33-39.

[8] Jiantuan Hu. Influence Factor and Way of the Coordinated Development of Information Teaching Ability for Urban and Rural Teachers[J].Science and Technology Innovation Herald, 2017(1):124-125.

[9] Rui Zhang, Dequan Zhu. Integration Research on Development of Course Resources of Vocational Education and Information Technology Under the Background of Urban and Rural Balance[J]. E-education Research, 2010(10):86-90.

[10]Zhonghou Wang, Dequan Zhu. Research on Information Resources Sharing of Vocational Education Under the Background of Urban and Rural Balance[J]. E-education Research, 2011(1):77-80.

[11]Jian Zhao. On Professional and Interacted Development Pattern in Urban and Rural for Teachers Under the Theory and Prospective of Transmission[J]. E-education Research, 2009(12):16-19.

[12] Li Liang, Changcheng Wu. Investigation and Research on Application Ability of Modern Distance Learning Resources for Rural Teachers of Middle and Primary Schools in Ningxia Area[J].E-education Research, 2010(5):56-59.

[13] Jizong Wei, Yaling Meng, Lichang Zhang. Investigation and Analysis on Information Literacy of College Students in the North of Shaanxi Province[J]. E-education Research, 2009(8):100-104.

[14]Feng Liu, Jihu Su. Research on Problems and Local Management Strategy of Distance Training[J]. E-education Research - With Workshops of Modern Distance Education Project for the Schoolmaster of Rural Middle and Primary School as Example[J]. E-education Research, 2010(4):113-117.

[15] Xin Li. Achievement Analysis of Modern Distance Education Project Construction in Rural Middle and Primary Schools[J]. E-education Research, 2009(2):87-92.

[16] Jian Zhao, Ju Hu. Establishing Country-centered Supply System for Rural Distance Education[J]. E-education Research, 2008(3):76-80. 
[17]Zhaojun Li, Tiegang Gao. Research on Evaluation Object and Evaluation Method of RDE Project[J]. E-education Research, 2009(4):65-68.

[18] Xiaolan Zhang, Rumei Ouyang. Design for TV Training Materials With Describing Type of Presenter - Perspective of Practice Applied in Three Modes of RDE Project[J]. E-education Research, 2010(5):80-83.

[19] Yuesheng Wang, Guoqiang Zhang, Xin Ma. Practice and Research Based on the School-based Training of RDE Project[J]. E-education Research, 2009(5):68-70.

[20] Hongjun Chen, Yuesheng Wang, Guoqiang Zhang. Exploration of Practice of Educational Technology Relied on RDE Project[J]. E-education Research, 2010(2):94-96.

[21] Gaixue Yang, Yanli Wang. Application of Bilingual Teaching Resources of Western Tibetan Nationality Under the Background of RDE Project[J]. E-education Research, 2010(6):55-59. 